\title{
Original
}

\section{Molecular Mechanisms of Cell Death Induction by Nedaplatin in Human Tumor Cell Lines}

\author{
Shigeki Sunaga, Masataka IIda, Nobuo Hirota, Seiji Shioda * \\ Hiroshi SAKagami ${ }^{* *}$, Minoru TAKeda $^{* *}$ and Kiyoshi Matsumoto
}

\begin{abstract}
Nedaplatin is an antitumor agent which is used to treat neural, cervical, lung, esophagus, and bladder cancer. To elucidate the mechanism of cell death induced by nedaplatin, we compared tumor cell lines of different lineages: glioblastoma (T98G), an ectodermal cell line, and promyelocytic leukemic cells (HL-60), a mesenchymal cell line. Nedaplatin induced apoptotic cell death (characterized by internucleosomal DNA cleavage of 180 to 200 base pair multiples) in HL-60 cells, but induced necrotic changes without induction of DNA laddering pattern in T98G cells. To examine the effect of nedaplatin on protease activities that are believed to be involved in apoptosis, activities of interleukin $1 \beta$ converting enzyme (ICE) family proteases, ICE protease and apopain, were examined using synthetic substrates in place of endogenous substrate poly (ADP-ribose) polymerase. Nedaplatin activated apopain only in HL-60 cells but failed to activate ICE protease in either cell line. Immunoblot analysis with anti-bcl-2 antibody demonstrated that the 24-kDa protein was only expressed in the cytosol of nedaplatin-treated T98G cells. The present study demonstrates that nedaplatin triggers different signal transduction pathways for cell death induction among cells of different origin.
\end{abstract}

Key words : cell death, apoptosis, necrosis, bcl-2, ICE family protease

\section{Introduction}

Programmed cell death occurs primarily through an evolutionarily conserved form of cell suicide termed apoptosis ${ }^{1}$. The determining factors for a cell to undergo apoptosis can be influenced by a wide variety of regulatory stimuli ${ }^{1}{ }^{1}$. Apoptosis is a genetically encoded cell death program defined by characteristic morphologic and biochemical changes ${ }^{2)}$. Apoptosis also can be induced in certain cell types by ionizing radiation and by many of the DNAdamaging drugs used in cancer treatment ${ }^{3)}$. Malignant gliomas are the most common malignant brain tumors and are considered incurable ${ }^{4)}$. The infiltrative growth pattern of these tumors precludes curative neurosurgery. These malignant tumor cells do not respond to irradiation, chemotherapy, or immunotherapys). Malignancy has been recognized to result not only from up-regulation of cell proliferation but also from down-regulation of

\footnotetext{
Department of Neurosurgery, Showa University School of Medicine, 1-5-8 Hatanodai, Shinagawa-ku, Tokyo 1420064, Japan

* Department of Anatomy, Showa University School of Medicine, ** Department of Biochemistry, Showa University School of Medicine,
} 
programmed cell death ${ }^{6,7)}$. Mechanisms of cell death induction have not yet been elucidated.

The interleukin $1 \beta$ converting enzyme (ICE) gene, which is a mammalian homologue of the Caenorhabiditis elegans cell death gene ced-3, has been identified as an inducer of apoptosis in Rat-1 fibroblasts and chicken ganglion neurons ${ }^{8,9)}$. The bcl-2 protein neutralizes an unknown cellular activator of apopain/CPP32 to prevent cells from entering the cell death pathway ${ }^{10)}$.

Nedaplatin is an antitumor agent derived from cisplatin. To understand the mechanism of action of nedaplatin on different lineages of tumor cells, such as T98G cells (ectodermal origin) and HL-60 cells (mesenchymal origin), morphologic changes, ICE family protease activity, and bcl-2 expression were investigated. HL-60 cells have been used as target cells for the study of apoptosis and cell death signal transduction. Because T98G cells and HL-60 cells are of different lineages, we compared the mechanisms of action of cell death induction by nedaplatin in these cell lines.

\section{Materials and Methods}

\section{Materials}

The following chemicals and reagents were obtained from the indicated companies: RPMI1640 medium (Gibco, Grand Island, NY), fetal bovine serum (FBS), (Filtron PTY Ltd., Australia), nedaplatin (Shionogi Pharmaceutical Co., Ltd., Tokyo, Japan), 3-[4,5dimethylthiazol-2-yl]-2,5-diphenyltetrazolium bromide (MTT), (Sigma, Chemical, Co., St. Louis, MO), dimethyl sulfoxide (DMSO), Apoptosis Ladder Detection Kit (Wako Pure Chemical, Industrics, Ltd., Osaka, Japan), phosphate-buffered saline (PBS), (Takara Biomedicals, Ootsu, Japan), substrate for apopain (Ac-Asp-Glu-Val-Asp-MCA), inhibitor of apopain (Ac-Asp-Glu-Val-Asp-H), substrate for ICE (Ac-Tyr-Val-Ala-Asp-MCA), and anti-bcl-2 antibody (Santa Cruz Biotechnology, Inc. California, USA). Nedaplatin (powder form) (supplied by Shionogi Pharmaceutical Co., Ltd.) was dissolved in fresh medium at a concentration of $1 \mathrm{mM}$.

Cell lines and cell culture

T98G and HL-60 cells (supplied by Riken Cell Bank, Tsukuba, Japan) were cultured at $37^{\circ} \mathrm{C}$ in RPMI 1640 medium supplemented with $10 \%$ FBS, 50 units $/ \mathrm{ml}$ penicillin $\mathrm{G}$, and $50 \mu \mathrm{g} / \mathrm{ml}$ streptomycin sulfate in a humidified $5 \% \mathrm{CO}_{2}$ atmosphere.

Assay for cytotoxicity

T98G cells were detached by trypsinization, seeded $\left(1 \times 10^{4}\right.$ cells $)$ to each 96-microwell plate (Nunc, InterMed, Roskilde, Denmark), and incubated for 24 hours before treatment. T98G cells and HL-60 $\left(1 \times 10^{6} / \mathrm{ml}\right)$ cells were treated for the indicated times in fresh culture medium containing various concentrations of nedaplatin. Numbers of viable HL-60 cells were determined by trypan blue exclusion ${ }^{11}$. The relative numbers of adherent viable T98G cells were determined by the MTT method. In brief, T98G cells were incubated for 4 hours in fresh culture medium containing $0.1 \mathrm{mg} / \mathrm{ml}$ MTT reagent. The washed cells were lysed with $0.1 \mathrm{ml}$ of DMSO, and the relative number of viable cells was expressed as the absorbance at $590 \mathrm{~nm}$ measured with an Immuno Reader NJ-2000 (InterMed) ${ }^{12}$.

Examination of morphologic changes

HL-60 cells in suspension were collected on slides by centrifugation (Cytospin 2, Shandon Southern Product Ltd., England), and fixed and stained with May-Grünwald/Giemsa solutions $^{11)}$. T98G cells were dispensed onto 8-chamber slides (Nunc, InterMed) at an 
initial inoculation of $1 \times 10^{5} \mathrm{cells} / \mathrm{ml}$ and cultured for 24 hours. These cells were treated with $1 \mathrm{mM}$ nedaplatin for 24 hours and stained as described above.

Electron microscopic examination was performed as follows. T98G and HL-60 cells were incubated for 24 hours with or without $1 \mathrm{mM}$ nedaplatin. Cells were washed three times with PBS and fixed in $2 \%$ glutaraldehyde in $0.1 \mathrm{M}$ phosphate buffer (PB, pH 7.2) for 3 hours and in $1 \% \mathrm{OsO}_{4}$ in $0.1 \mathrm{M} \mathrm{PB}$ for 30 minutes. Cells were subsequently dehydrated with a graded series of ethanol, infiltrated with propylene oxide, and embedded in an Epon-Araldite mixture. Ultrathin sections were stained with uranyl acetate and lead citrate and observed with an electron microscope (JEM 1200 EX II, JEOL, Tokyo, Japan).

Assay for DNA fragmentation

The cells were treated for 8 hours with or without nedaplatin in $1 \mathrm{ml}$ of culture medium in a 24-well plate (Nunc, Inter Med). T98G cells were harvested by scraping with a rubber policeman in ice-cold PBS. Cells were pelleted by centrifugation and immediately lysed in $20 \mu 1$ lysis buffer (50 mM Tris-HCl [pH 7.8], $10 \mathrm{mM}$ EDTA, and $0.5 \%$ [w/v] sodium N-lauryl sarcosinate). Cells were sequentially digested with $0.5 \mathrm{mg} / \mathrm{ml}$ RNase A for 60 minutes at $50^{\circ} \mathrm{C}$ and $0.5 \mathrm{mg} / \mathrm{ml}$ proteinase $\mathrm{K}$ for 60 minutes at $50^{\circ} \mathrm{C}^{13)}$. The resultant DNA preparations were directly applied to $1.8 \%$ agarose gel electrophoresis in TBE buffer (89 $\mathrm{mM}$ Tris-HCl, $89 \mathrm{mM}$ boric acid, and $2 \mathrm{mM}$ EDTA [pH 8.0]). Eco T141 digests of $\lambda$ DNA (Takara Biomedicals) were used as molecular size markers. The DNA fragmentation pattern was examined in photographs taken under UV illumination.

Assay for Apopain and ICE activity

Apopain/CPP32 and ICE protease activity was assayed with the fluorometric method using the specific substrate (Ac-Asp-Glu-Val-Asp-MCA, Ac-Try-Val-Ala-Asp-MCA).

Adherent T98G cells $\left(1 \times 10^{7}\right.$ cells $\left./ \mathrm{ml}\right)$ and HL-60 cells in suspension $\left(1 \times 10^{6}\right.$ cells $\left./ \mathrm{ml}\right)$ were incubated for 12 hours with fresh culture medium containing 0 or $1 \mathrm{mM}$ nedaplatin. The cells were harvested and immediately lysed in $100 \mu 1$ reaction buffer $(0.1 \mathrm{M}$ MOPS-NaOH [pH 7.4] and $2 \mathrm{mM} \mathrm{CaCl}$ ), and sonicated twice in an ice-cold water bath. The cell lysate was centrifuged $(15,000 \mathrm{rpm})$ for 10 minutes at $4^{\circ} \mathrm{C}$ in an Eppendorf microtube. To $25 \mu 1$ supernatant of lysate, $450 \mu 1$ reaction buffer and $5 \mu 1$ substrate were added, and the mixture was incubated at $37^{\circ} \mathrm{C}$ for 60 minutes. The enzyme reaction was terminated by the addition of stopper (0.2 M Gly- $\mathrm{HCl}[\mathrm{pH} 2.8])$. The enzymic degradation of the substrate was monitored continuously with a fluorescence spectrophotometer (650-10S, Hitachi, Ltd., Tokyo, Japan) at an excitation wavelength of $380 \mathrm{~nm}$ and an emission wavelength of 460 $\mathrm{nm}^{14)}$. As a standard, the reaction mixture that contained the indicated concentrations of 7-amino-4-methylcoumarin (AMC) and $100 \mathrm{Um}^{-1}$ of the purified PARP-cleavage CPP-32 enzyme (1U represents 1 pmol AMC liberated per minute at $37^{\circ} \mathrm{C}$ at saturating substrate concentration) were run in parallel.

\section{Assay for apopain inhibitor}

To examine the involvement of apopain in cell death induced by nedaplatin, a synthetic peptide, Ac-Asp-Glu-Val-Asp-H (aldehyde), was used as an inhibitor of apopain. This inhibitor $(100 \mu \mathbf{M})$ was added 1 hour before the addition of nedaplatin ${ }^{14)}$. The cells were incubated for 12 hours with $1 \mathrm{mM}$ nedaplatin. The medium was removed, and the cells were incubated for a further 12 hours to determine the number of viable cells.

Analysis of bcl-2 product

Adherent T98G cells $\left(1 \times 10^{7} / 20 \mathrm{ml}\right.$ medium in $10-\mathrm{cm}$ dish $)$ or HL-60 cells in suspension 

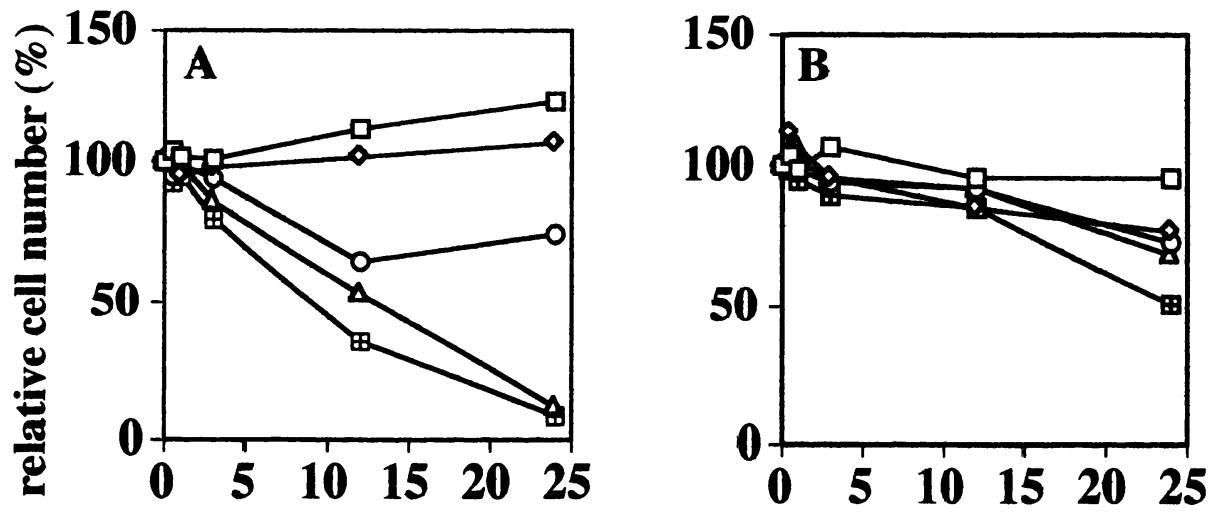

Incubation time (h)

Fig. 1. Cytotoxic activity of nedaplatin against T98G and HL-60 cells. HL-60 (A) or T98G (B) cells were treated for the indicated times with $0(\square), 1(\diamond), 10(\bigcirc), 100(\Delta)$, or 1000 (田) $\mu \mathrm{M}$ nedaplatin, and the numbers of viable cells were determined with trypan blue exclusion and the MTT method, respectively. Each value represents mean \pm S.D. from four determinations.

$\left(2 \times 10^{7} / 20 \mathrm{ml}\right)$ were incubated for 12 hours with fresh medium containing 0 or $1 \mathrm{mM}$ nedaplatin. The cells were washed three times with PBS and disrupted with $1.0 \mathrm{ml}$ of RIPA buffer (PBS, $1 \%$ NP40, $0.5 \%$ sodium deoxycholate, and $0.1 \%$ SDS). After homogenization at $0{ }^{\circ} \mathrm{C}$ by sonication, $10 \mu 1$ of $10 \mathrm{mg} / \mathrm{ml}$ PMSF stock was added and chilled on ice for 30 minutes. These samples were centrifuged at $15,000 \mathrm{~g}$ for 20 minutes at $4^{\circ} \mathrm{C}$ to obtain the supernatant (total cell lysate). The total cell lysate was mixed with an equal volume of electrophoresis sample buffer $(1.0 \mathrm{ml}$ glycerol; $0.5 \mathrm{ml} \beta$-mercaptoethanol; $3.0 \mathrm{ml}$ of $10 \%$ SDS ; $1.25 \mathrm{ml} 1.0 \mathrm{M}$ Tris- $\mathrm{HCl}$ [pH 6.7]; 1 to $2 \mathrm{mg}$ bromophenol blue) and boiled for 90 seconds. Ten microliters of lysate was placed into each well on top of an $12.5 \%$ polyacrylamide slab gel. After electrophoresis, proteins were transferred with an electroblotting apparatus from the gel to a nitrocellulose membrane and were blocked in 1 $\%$ milk for about 30 minutes. Each membrane was reacted with $1 \mu \mathrm{g} / \mathrm{ml}$ primary antibody (goat Bcl-2 [N-19]) overnight at $4{ }^{\circ} \mathrm{C}$. Each membrane was then reacted with secondary antibody (horseradish peroxidase [HRP]-conjugated anti-goat [Dako, Glosrrup; Denmark] at $1: 1000$ dilution) for about 60 minutes at room temperature.

\section{Results}

\section{Cytotoxic activity of nedaplatin}

T98G and HL-60 cells that had grown exponentially were treated with nedaplatin. Nedaplatin was more cytotoxic against HL-60 cells than against T98G cells (Fig. 1). The $50 \%$ cytotoxic concentration $\left(\mathrm{CC}_{50}\right)$ of nedaplatin against HL-60 cells after incubation for 12 hours was $100 \mu \mathrm{M}$ (Fig. 1A). Similarly, the $\mathrm{CC}_{50}$ of nedaplatin against T98G cells after 24 hours was $1000 \mu \mathrm{M}$ (Fig. 1B).

\section{Morphologic changes}

T98G cells were grown as an adherent monolayer. Under a phase-contrast microscope, the cells showed polygonal morphology with neurites. Cells stained with May-Grünwald- 


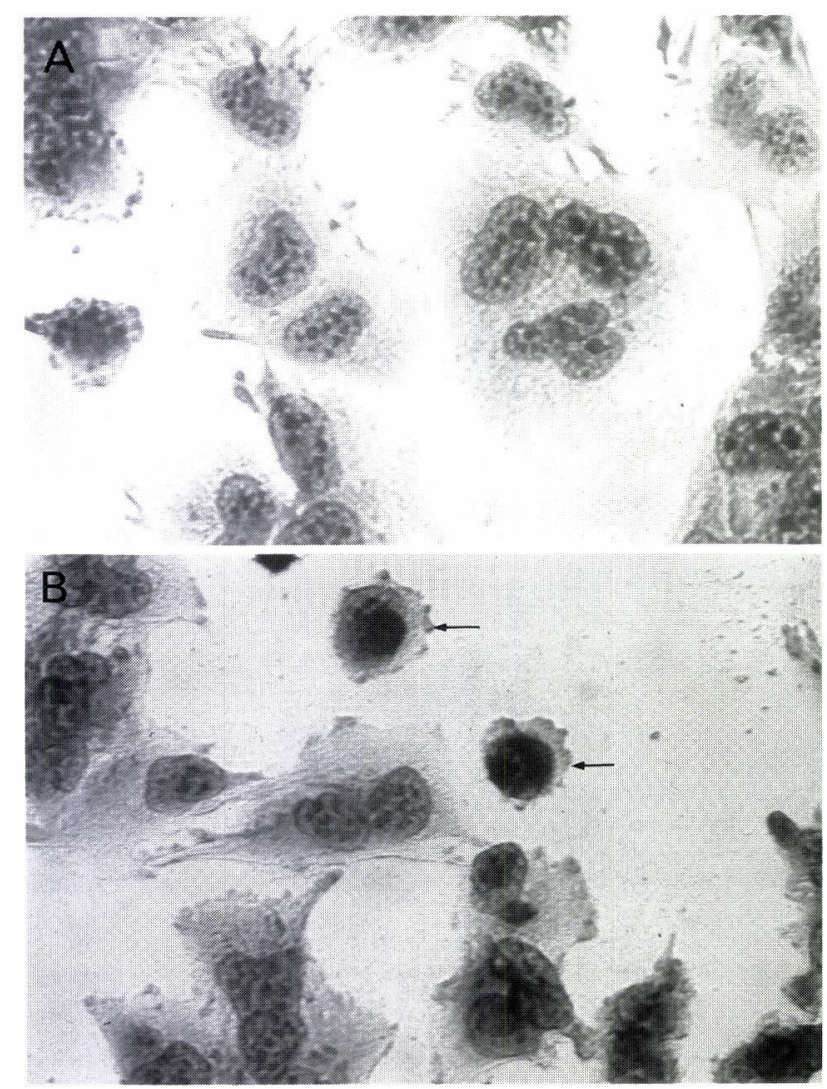

Fig. 2. Effect of nedaplatin on the morphology of T98G cells. T98G cells were treated for 24 hours without (A) or with (B) $1 \mathrm{mM}$ nedaplatin. Narrow cytoplasm and pyknotic chromatin are indicated by arrows. A, B : $\times 200$.

Giemsa stain possessed round or ovoid nuclei with a prominent nucleolus and relatively scant cytoplasm. Nedaplatin-treated T98G cells had narrow cytoplasm and pyknotic chromatin but no apparent nuclear fragmentation (Fig. 2). HL-60 cells proliferated in a suspension culture. Exposure of HL-60 cells to nedaplatin induced nuclear fragmentation and cellular budding and finally produced membrane-bound apoptotic bodies (Fig. 3).

Electron microscopy revealed that control T98G cells had large nuclei with a nucleolus and scant cytoplasm with dense bodies; the Golgi apparatus, mitochondria, and cell surface microvilli were usually visible (Fig. 4A). Nedaplatin treatment ( $1 \mathrm{mM}, 24$ hours) induced morphologic changes (Fig. 4B-4F), such as nuclear and cytoplasmic condensation and shrinkage and swelling of the mitochondria. At a later stage (Fig. 4E, 4F), the cells had some autophagic vacuoles and lipid droplets. These morphologic changes suggest that cell death of $\mathrm{T} 98 \mathrm{G}$ cells was necrosis.

Next, we investigated the effect of nedaplatin on HL-60 cells (Fig. 5A, 5B). Nedaplatin treatment induced compaction and margination of nuclear chromatin, condensation of cytoplasm, and convolution of nuclear and cell outlines. These changes were followed by nuclear fragmentation and budding of cells producing membrane-bound apoptotic bodies (Fig. 5B). 


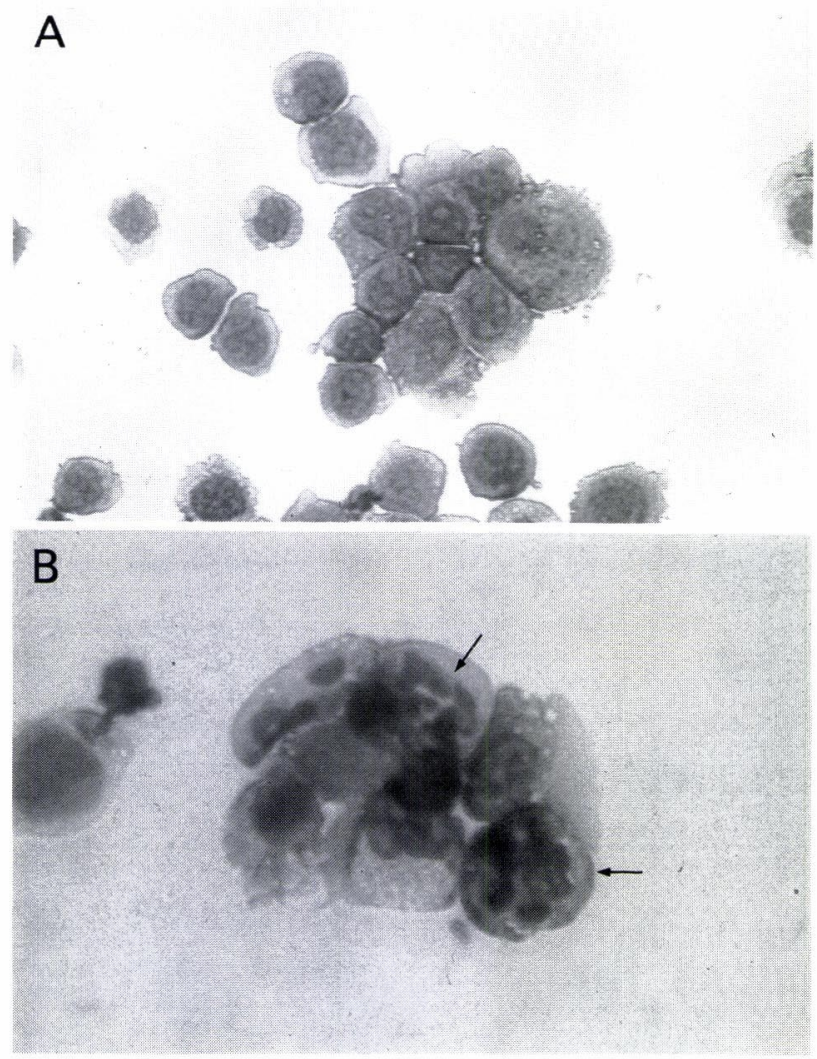

Fig. 3. Effect of nedaplatin on the morphology of HL-60 cells. HL-60 cells were treated for 24 hours without (A) or with (B) $1 \mathrm{mM}$ nedaplatin. Arrow shows nuclear fragmentation. A : $\times 200$. B : $\times 400$.

\section{Induction of DNA fragmentation}

Treatment of HL-60 cells with nedaplatin ( $1 \mathrm{mM}, 8$ hours) induced internucleosomal DNA cleavage of 180 to 200 base-pair multiples (lane 2 in Fig. 6A) ${ }^{15}$. On the other hand, nedaplatin did not produce any cell shrinkage, nuclear fragmentation, or internucleosomal DNA cleavage in T98G cells (Fig. 6B).

Effect on protease activity

Apopain activity was measured at various time points after nedaplatin treatment with its specific substrate (Ac-Asp-Glu-Val -Asp-MCA) (Fig. 7). In HL-60 cells, apopain activity was increased after 1 hour, and reached a maximal level after 2 hours (Fig. 7A). Basal apopain activity in T98G cells was significantly lower than that in HL-60 cells and was not significantly affected by nedaplatin treatment (Fig. 7B). ICE protease activity was measured with its specific substrate (Ac-Try-Val-Ala-Asp-MCA). During culture without nedaplatin, ICE protease activity was slightly increased, but the addition of nedaplatin did not significantly affect enzyme activity in either HL-60 (Fig. 8A) or T98G cells (Fig. 8B). Effect of apopain inhibitor

The apopain inhibitor (Ac-Asp-Glu-Val-Asp-H) $(100 \mu \mathbf{M})$ significantly reduced the cytotoxic activity of nedaplatin in HL-60 cells (Fig. 9). 


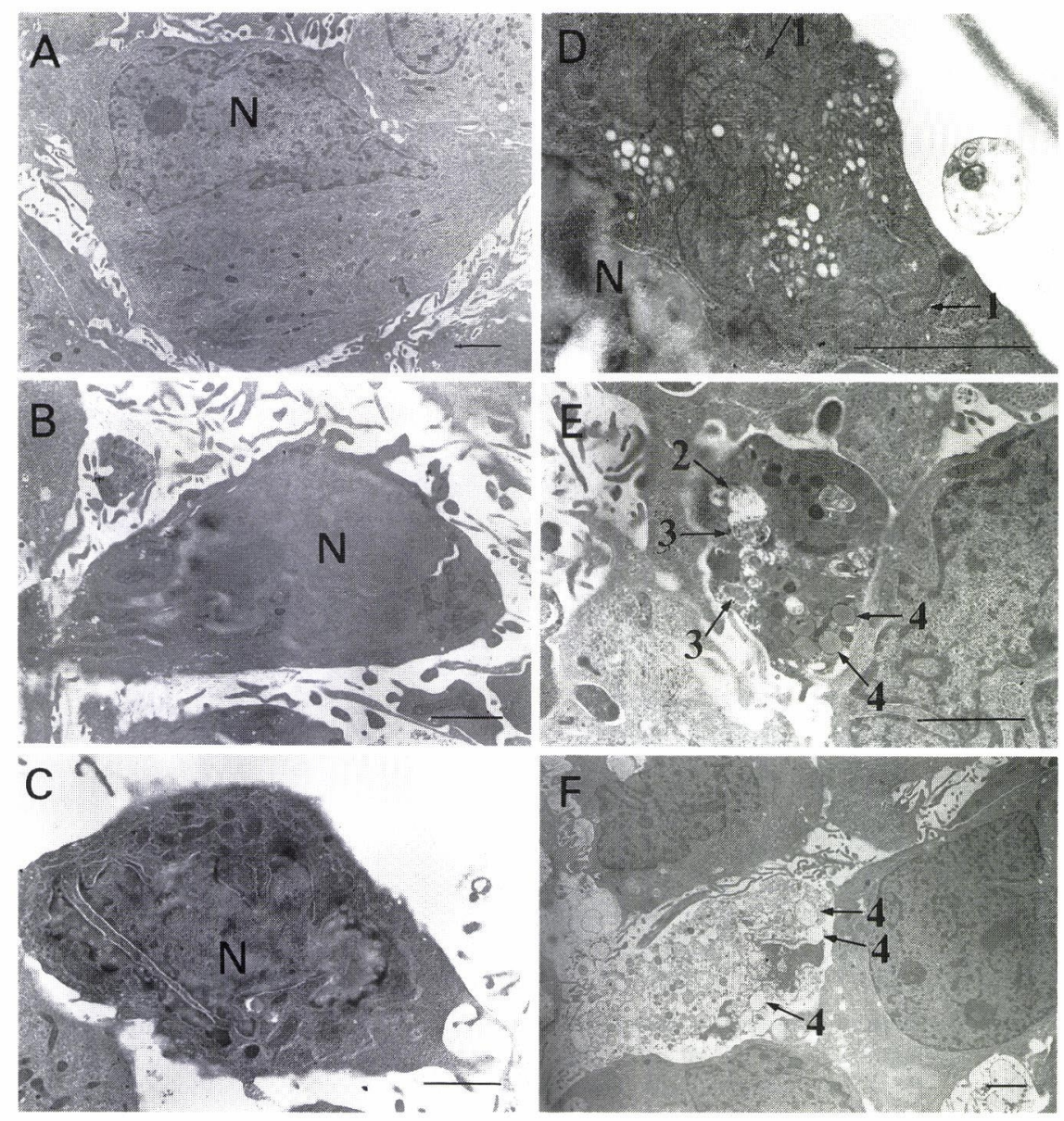

Fig. 4. Electron microscopic observation of control (A) and nedaplatin (1 mM, 24 hours)-treated T98G cells (B-F). Mitochondria (arrow 1), autophagic vacuole (arrow 2), lysosome (arrow 3 ), lipid droplets (arrow 4), N : nucleus. A : $\times 3750$. B,C: $\times 6000 . \quad \mathrm{D}: \times 15000$. E: $\times 7500$. F : $\times 3000$. Scale bar $=2 \mu \mathrm{m}$.

\section{Analysis of bcl-2 protein by immunoblotting}

Immunoblotting with antibodies specific for bcl-2 showed the presence of a 24-kD protein in nedaplatin-treated T98G cell lysate (lane 3 in Fig. 10). Lysates of control T98G cells (lane 2), and control and nedaplatin-treated HL-60 cells did not react with anti-bcl-2 antibody (lane 4, 5 in Fig. 10).

\section{Discussion}

We investigated the effects of nedaplatin, an antitumor agent, on human tumor cell lines of different lineages. Usually, nedaplatin is used to treat neural, cervical, lung, esophagus, and bladder cancers. We were interested in how nedaplatin induces cell death in human tumors cells from different sources, including those originating from ectodermal cells (glioblastoma) and from mesenchymal cells (promyelocytic leukemia cells). The pattern of cell death has been classified into two categories, apoptosis and necrosis, on the basis of 


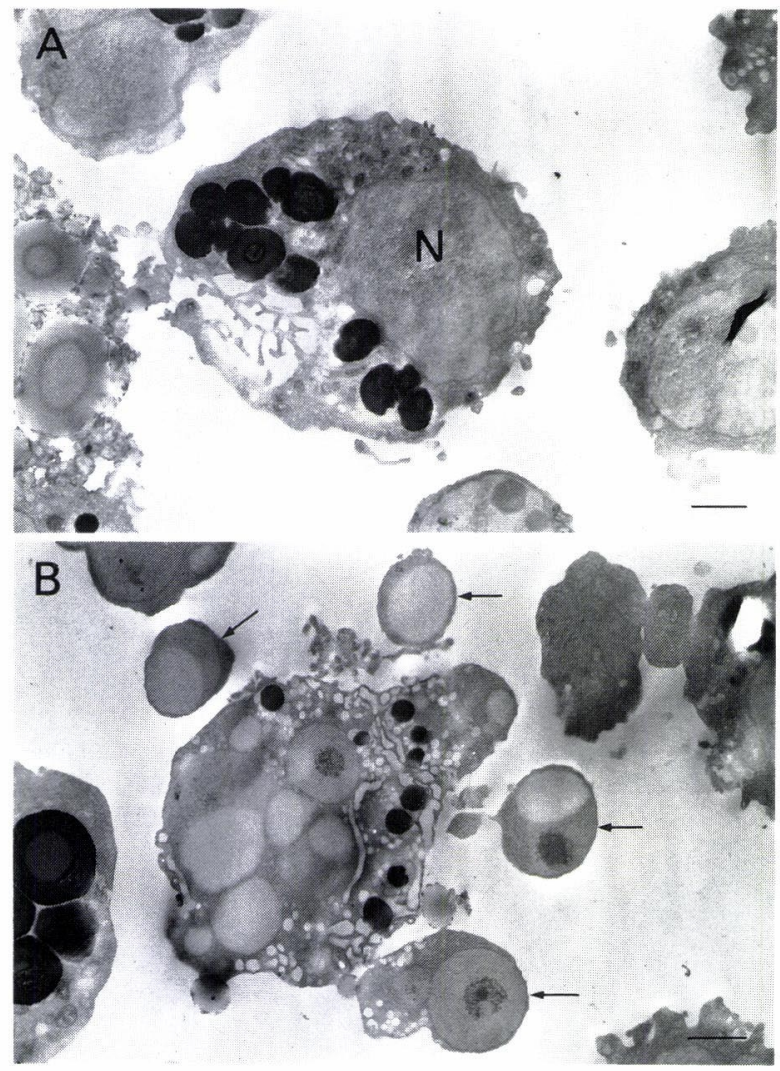

Fig. 5. Electron microscopic observation of control (A) and nedaplatin (1 mM, 24 hours)-treated HL-60 cells (B). Apoptotic bodies (arrow). A : $\times 7500$. B : $\times 7500 . \quad \mathrm{N}:$ nucleus. Scale bar $=1 \mu \mathrm{m}$.
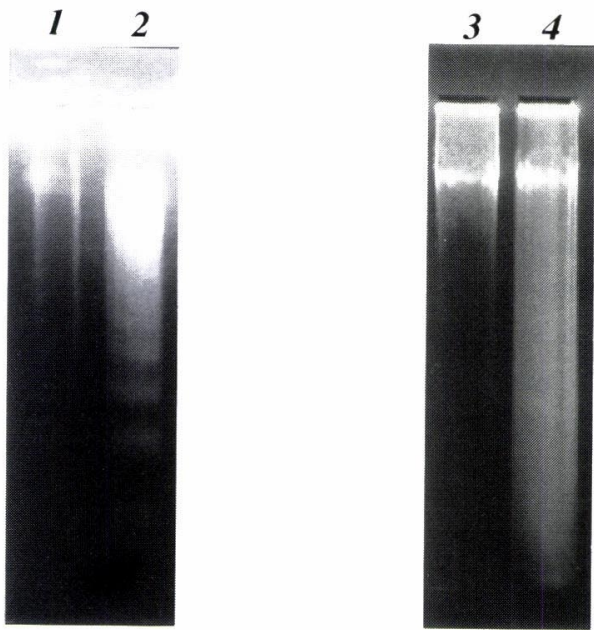

\section{A:HL-60}

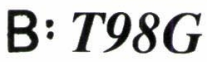

Fig. 6. Effect of nedaplatin on DNA fragmentation in HL-60 (A) or T98G (B) cell lines. lane 1 : control (without nedaplatin). lane 2 : nedaplatin treated ( $1 \mathrm{mM}, 8$ hours). 


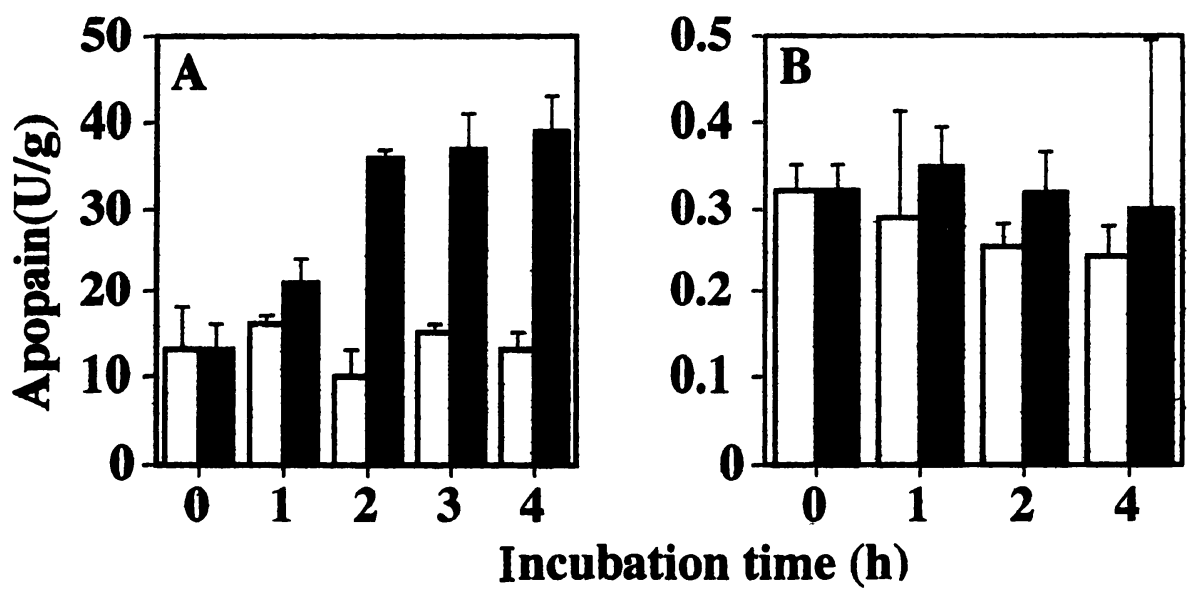

Fig. 7. Effect of nedaplatin on apopain activity in HL-60 (A) and T98G (B) cell lines. T98G and HL-60 cells were incubated without nedaplatin $(\square)$ or with $1 \mathrm{mM}$ nedaplatin ( $\square$ ) in apopain. Each value represents mean \pm S.D. from four determinations.

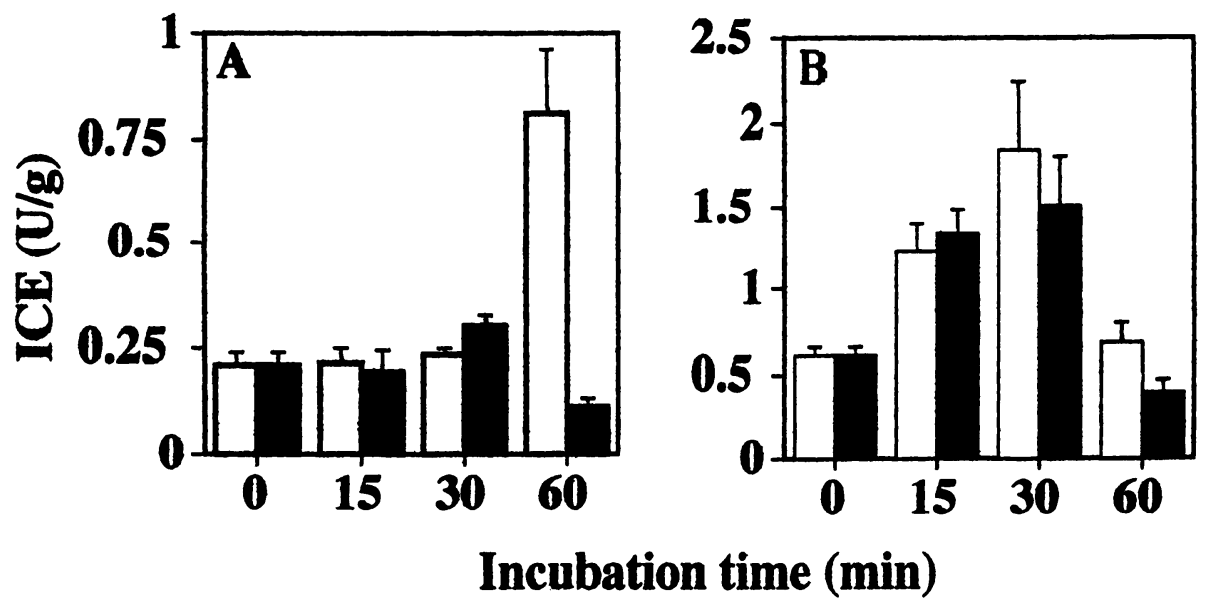

Fig. 8. Effect of nedaplatin on ICE protease activity in HL-60 (A) and T98G (B) cell lines. T98G and HL-60 cells were incubated without nedaplatin $(\square)$ or with $1 \mathrm{mM}$ nedaplatin $(\square)$ in apopain. Each value represents mean \pm S.D. from four determinations.

intracellular structure ${ }^{16)}$. The two processes are associated with different patterns of DNA degradation ${ }^{17)}$. Extensive studies have demonstrated that these two types of cell death are distinct ${ }^{18)}$. Thus, necrosis is always the outcome of severe and sudden cellular injury, such as ischemia, sustained hyperthermia, and physical and chemical trauma ${ }^{19)}$. Apoptosis occurs in normal tissues and, where it is observed pathologically, a homeostatic function can often be attributed. Recent studies have suggested the involvement of a protease belonging to the ICE/CED-3 family in Fas-mediated apoptosis ${ }^{20)}$. Apopain is a key ICE-like protease in Fas-mediated apoptosis ${ }^{21}$.

Programmed cell death in Caenorhabiditis elegans is negatively regulated by ced- $9^{10)}$. The mammalian homologue of ced-9 is the proto-oncogene product bcl- $2^{10)}$. The two proteins 


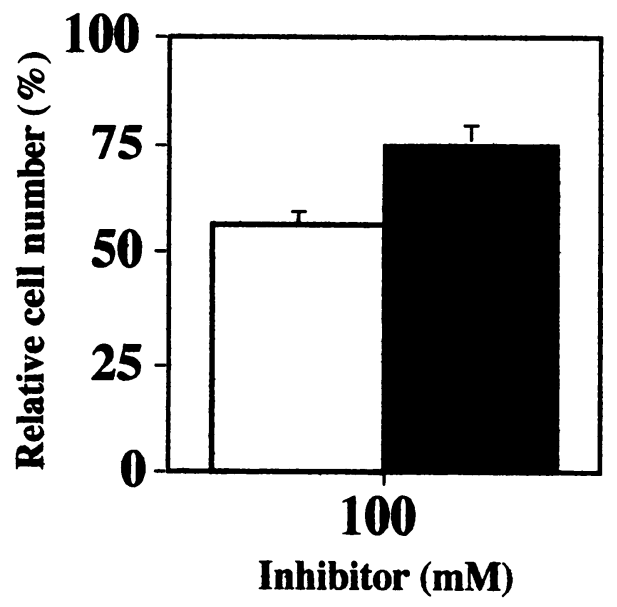

Fig. 9. Effect of an apopain inhibitor on the cytotoxic activity of nedaplatin. HL-60 cells were incubated for 12 hours without (control) or with $1 \mathrm{mM}$ nedaplatin in the absence $(\square)$ or presence ( $\square$ ) of $100 \mu \mathrm{M}$ apopain inhibitor. Each value represents mean \pm S.D. from four determinations.

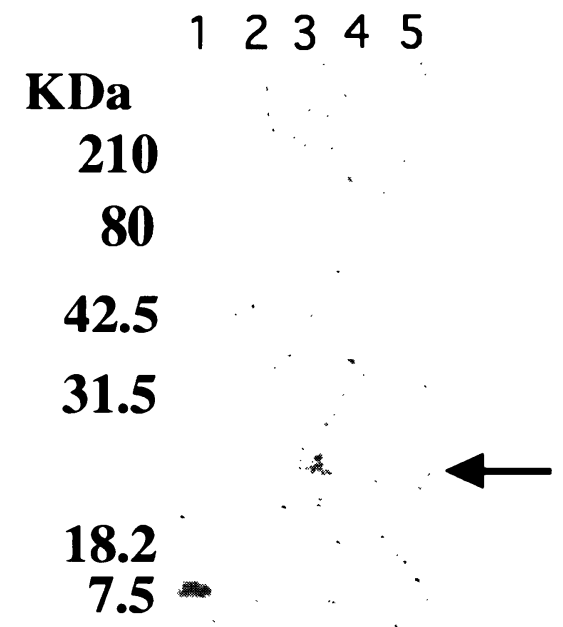

Fig. 10. Detection of a $24-k D$ protein (bcl-2) in cell lysate (arrow). lane 1 : marker. lane 2 : control T98G cells (without nedaplatin). lane 3 : nedaplatin ( $1 \mathrm{mM}, 12$ hours)-treated in T98G cells. lane 4 : control HL-60 cells (without nedaplatin). lane 5 : nedaplatin ( $1 \mathrm{mM}, 12$ hours)-treated in HL-60 cells.

are functionally interchangeable such that bcl-2 suppresses a ced-9 loss-of-function phenotype in Caenorhabiditis elegans ${ }^{10)}$. Analogous to ced-9, bcl-2 may impair the proper functioning of the ICE-like protease apopain/CPP32/Yama ${ }^{10)}$.

In our study, HL-60 cells were genetically encoded with a cell death program defined by characteristic morphologic and biochemical changes. During cell death in HL-60 cells, apopain activity, but not ICE protease activity, was significantly increased. A significant 
role for apopain in nedaplatin-induced cell death is further supported by our finding that an apopain inhibitor significantly reduced apoptosis. The initial step in the activation of apopain may be perfomed by upstream proteases other than ICE protease, or another heterologous signal system may be involved. Nedaplatin induced necrotic changes in T98G cells, without induction of internucleosomal DNA cleavage or activation of ICE protease or apopain. We found that nedaplatin treatment of T98G cells induced expression of a 24-kD protein, which reacted with bcl-2 antibody. The expression of this protein may confer this cell line with resistance to nedaplatin or block ICE family proteases.

We have not yet answered the question of why nedaplatin acts differently on these different cell types. The difference might be due to differences in cell origin or in action points, including that of the signal transduction process of cell death. Further studies are required to clarify the role of bcl-2 protein and caspases activated during the induction of cell death.

\section{Acknowledgment}

The authors thank Shionogi Pharmaceutical Co. Ltd., Tokyo for the supply of nedaplatin, and Dr. S. Hongo, S. Iwamoto, and T. Hagiwara for their generous instruction of experimental technique.

\section{References}

1) Thompson CB : Apoptosis in the pathogenesis and treatment of disease. Science, $267: 1456-1462$ (1995)

2) Wyllie AH : Cell death. Int Rev Cytol, $17: 755-785$ (1987)

3) Kondo S, Yin D, Morimura $\mathrm{T}$ and Takeuchi $\mathrm{J}$ : Combination therapy with cisplatin and nifedipine induces apoptosis in multi-drug resistant human glioblastoma cells. J Neurosurg, 82 : 469-474 (1995)

4) Schoenberg BS: The epidemiology of central nervous system temors. In: Oncology of the Nervous System, Walker MD (Ed.), Nijhoff, Boston, pp 1-30 (1983)

5) Deen FD and Chiarado A : Brain Tumor Working Group report on the 9th International Conference on Brain Tumor Research and Therapy. J Neuro-Oncol, $16: 243-272$ (1993)

6) Weller M, Frei K, Groscurth P, Krammer PH, Yonekawa Y and Fontana A : Anti-Fas/APO-1 antibodymediated apoptosis of cultured human glioma cells, induction and modulation of sensitivity by cytokines. $J$ Clin Invest, 94 : 954-964 (1994)

7) Korsmeyer SJ : Bcl-2 : an antidote to programmed cell death. Cancer Surv, 15 : 105-118 (1992)

8) Miura M, Zhu H, Rotello R, Hartwieg EA and Yuan J: Induction of apoptosis in fibroblasts by IL-1b-converting enzyme, a mammalian homolog of the C. elegans cell death gene ced-3. Cell, 75:653-660 (1993)

9) Gagliardini V, Femandez P-A, Lee RKK, Drexler HCA, Rotello R. J, Fishman MC, and Yuan J : Prevention of vertebrate neuronal death by the crmA gene. Science, $263: 826-828$ (1994)

10) Laurent $\mathbf{M}$, Isabelle $O$, Reynald $O$, Ulla R, Hengameh $M$, Isabelle F, Guy GP and Christoph B : Bcl-2 overexpression blocks activation of the death protease CPP32/Yama/Apopain. Biochem Biophys Res Commun, 221 : 340-345 (1996)

11) Sakagami H, Kurubayashi N, Iida M, Hagiwara T, Takahashi H, Yoshida H, Shiota F, Ohata H, Momose K and Takeda $\mathbf{M}$ : The requirement for and mobilization of calcium during induction by sodium ascorbate and by hydrogen peroxide of cell death. Life Sci, 58 : 1131-1138 (1996)

12) Sakagami H, Satoh K, Fukuchi K, Gomi K, and Takeda $\mathbf{M}$ : Effect of an iron-chelator on ascorbate-induced cytotoxicity. Free Radic Biol Med, 23 : 260-270 (1997)

13) Yanagisawa-Shiota F, Sakagami H, Kuribayashi N, Iida M, Sakagami T and Takeda M : Endonuclease activity and induction of DNA fragmentation in human myelogenous leukemic cell lines. Anticancer Res, $15: 259-266$ (1995)

14) Donald WN, Ambereen A, Nancy AT, John PV, Connie KD, Michel G and Douglas KM : Identification and inhibitor of the ICE/CED-3 protease necessary for mammalian apoptosis. Nature, $376: 37-43$ (1995)

15) Sakagami H, Satoh K, Ohata H, Takahashi H, Yoshida H, Iida M, Kuribayashi N, Sakagami T, Momose K and Takeda $\mathbf{M}$ : Relationship between ascorbyl radical intensity and apoptosis inducing activity. Anticancer Res, 16 : 2635-2644 (1996) 
16) Kerr JFR : An electron-microscope study of liver cell necrosis due to heliotrine. J Pathol, 97:557-562 (1969)

17) Afanas,ev VN, Korol, BA, Mantsygin YA, Nelipovich PA, Pechatnikov VA and Umansky SR: Flow cytometry and biochemical analysis of DNA degradation characteristic of two types of cell death. FEBS Letters, 194 : 374-350 (1986)

18) Cohen JJ and Duke RC: Apoptosis and programmed cell death in immunity. Ann Rev Immunol, $10: 267-293$ (1992)

19) Cohen JJ : Apoptosis. Immunol Today, $14: 126-130$ (1993)

20) Enari M, Hug H and Nagata S: Involvement of an ICE-like protease in Fas-mediated apoptosis. Nature, 375 : 78-81 (1995)

21) Schlegel J, Peters I, Orrenius S, Miller DK, Thornberry NA, Yamin T-T. and Nicholson DW: CPP32/ Apoptosis is a key interleukin lb converting enzyme-like protease involved in Fas-mediated apoptosis. $J$ Biol Chem, 271 : 1841-1844 (1996)

[Received January 14, 1998 : Accepted February 16, 1998] 